\title{
Accounting
}

\section{Firm size, business sector and quality of accounting information systems: Evidence from Vietnam}

\author{
Vu Thi Thanh Binh" ${ }^{a^{*}}$, Nhat-Minh Tran', Do Minh Thanh ${ }^{c}$ and Hiep-Hung Pham ${ }^{\text {d }}$
}

${ }^{a}$ Faculty of Accounting and Auditing, Hanoi University of Industry, Vietnam

${ }^{b}$ Faculty of Business Management, National Economics University, Vietnam

${ }^{c}$ Thuongmai University, Vietnam

${ }^{d}$ Center for Research and Practice in Education, Phu Xuan University, Vietnam

\begin{tabular}{l}
\hline C H R O N I C L E \\
\hline Article history: \\
Received November 282019 \\
Received in revised format \\
December 262019 \\
Accepted January 282020 \\
Available online \\
February 22020 \\
\hline Keywords: \\
Accounting information system \\
Business sector \\
Firm size \\
Quality of accounting information \\
system
\end{tabular}

A B S T R A C T

\begin{abstract}
This paper increases the understanding of the quality of accounting information systems in emerging economies, using data from Vietnam as an example. The quality of accounting information systems is a measure combining system quality and information quality. It is important to figure out what aspects of this measure are critical for business to enhance firm performance. This research investigates the level of accounting information system quality and examines the relationships between system quality and firm size, information quality and firm size, system quality and business sector as well as information quality and business sector, respectively. We employed descriptive statistics to illustrate the quality of accounting information systems and One-Way ANOVA to test four hypotheses. The descriptive statistics results demonstrate the level of system quality and information quality, in general, is not excellent. And there are differences in system quality and information quality in each business sector groups and firm size groups. The test result highlights a relationship between system quality and firm size but there are no links between information quality and firm size, system quality and business sector, and information quality and business sector. In conclusion, the paper extends the literature of the quality of accounting information systems and assists state agencies and executives to have a framework to improve the business performance as well.
\end{abstract}

(C) 2020 by the authors; licensee Growing Science, Canada

\section{Introduction}

The Industrial revolution $4^{\text {th }}$ (IR4.0) has a strong impact on accounting. The information processing of accounting information systems is changed. For example, recording information is computerized through the interface of accounting software while the processing of accounting information is performed by certain operations such as posting, closing entries or carrying forward (Chúc, 2015). The strong application of information technology to accounting field has required information quality not only in terms of information content but also format of information when it is provided to users (Gorla, Somers, \& Wong, 2010), and accounting information not only meets standards of quality specified in accounting regulations but also access safety issues (Nguyen, 2012). Accounting information system with the functions of producing and communicating information to stakeholders for specific purposes is an essential system in the firms. In Vietnam, accounting information in small and medium enterprises (SMEs) is not enough reliable for decision-making (Nguyen, 2018). Accounting information support for purposes of loan and tax obligations, not focus on providing information for decision making (Nguyen, 2018), whilst information

* Corresponding author

E-mail address: vuthithanhbinh@haui.edu.vn (V. T. T. Binh) 
processing in the accounting information systems mainly concentrates on applications supporting bookkeeping such as ledger accounts than the applications assisting financial analysis, budgeting, and project management (Binh, 2018). On the academic aspect, some researchers used single scale (Sajady, Dastgir, \& Nejad, 2008; Yap, Soh, \& Raman, 1992) while several other researchers, in recent years, have proposed using a multi-dimensional scale to assess the quality of accounting information systems (Chalu, 2012; Gorla et al., 2010). On the practical aspect, the Vietnamese Government has a lot of solutions, including accounting support, to sponsor the development of businesses in Vietnam (Government, 2018). However, there is a lack of evidence of the quality of accounting information systems and determinants that can lead to the ineffectiveness of the support solutions. Thus, researching on the quality of accounting information systems is essential in the Vietnam context. This research has two objectives comprising investigating the level of the quality of corporate accounting information systems and examining the relationship between the quality of accounting information system and firm size, and business sector, respectively. The research has a contribution to both academic and practical aspect. We consolidate a multidimensional measure framework for assessing the quality of accounting information systems. The results of the research notice for stakeholders like firms, state agencies the remarkable in the quality of accounting information systems regarding the practical aspect.

\section{Literature review}

AICPA state that accounting is an information system (AICPA, 1966). Romney and Steinbart (2015) define that accounting information system is "a system that collects, records, stores, and processes data to produce information for decision-makers" [page 10]. The accounting information system has six components which are people using the system, data, instructions and procedures, software, information technology infrastructure, and security measures and internal controls (Romney \& Steinbart, 2015). The accounting information system has many contributions to business firms comprising reducing the costs and increasing the quality of products, enhancing productivity, improving decision-making, sharing knowledge (Allahverdi, 2011). Meiryani (2015) define that quality of accounting information system is a consolidated system from the numerous elements of accounting information systems are linked and work together to transform financial data into useful information for the system users. Sačer and Oluić (2013) state that the quality of accounting information systems is the accounting system that meets the needs of external and internal users. And the level of integration between the accounting information system and other subsystems in the management information system determines its quality. Researchers have been paying attention to propose measurements or examine the determinants of the quality of accounting information systems. The measurement of accounting information systems quality is both illusive and complex (Petter, Delone, \& McLean, 2008). There are a lot of constructs to measure the quality of accounting information systems such as user satisfaction (Yap et al., 1992), organizational impact (Sajady et al., 2008). Delone and McLean (1992) proposed a combination measure of information systems quality, which includes system quality and information quality. Delone and McLean (2003) upgraded service quality dimension, however, Seddon and Kiew (1996) argued that service quality is not suitable for accounting information systems because the information system is not an IT department. Delone and McLean (2002) stated that system quality and information quality are the best measures for measuring the quality of information systems.

System quality: System quality is a critical measure in measuring the quality accounting information systems. System quality is used in the process of assessing the contribution of information systems to business activities and "describes measures of the information processing system itself” (Delone \& McLean, 1992). System quality measures the ability of information processing of the system itself and evaluates the software and system's data from a technical perspective (Gorla et al., 2010). System quality relates to whether or not exists a "bug" in the system, user interface consistency, ease of use, document quality and sometimes, the quality and maintainability of program encryption (Seddon, 1997). Gorla et al. (2010) use nine items to illustrate the characteristics of system quality including easy to learn, equipped with useful functions and features, flexible to make change easily, applied modern technology, well-integrated, user-friendly, good documentation, quick response to an online inquiry, short-time lag in batch processing.

Information quality: Information system focuses on the quality of outputs generated from the data processing (Delone \& McLean, 1992), which can be shown on the online screens or reporting forms (Gorla et al., 2010). Information quality refers to accuracy, suitability, and timeliness of information generated by the information system (Seddon, 1997). Kieso, Weygandt, and Warfield (2010) described the characteristics of information quality which refer to fundamental quality such as relevance, faithful representation and enhancing qualities like comparability, verifiability, timeliness, and understandability. In accounting information systems, Gorla et al. (2010) outlined two features of information quality, in which content and format have five items accurate, complete, concise, useful, relevant and three items good format and appearance, comparable to other outputs, easy to understand, respectively. Firm size belongs to firm characteristics that affecting the accounting information systems (Kieso et al., 2010). Firm size is determined by many factors such as the size of the market (Smith, 1776) or operation cost in businesses (Becker \& Murphy, 1992). Because small companies and large companies deal with different challenges, the firm size has a moderating effect on the business model transformation (Hartmann, Oriani, \& Bateman, 2013) and management information systems as well (Weill \& Olson, 1989). For more detail, the firm size impacts on the development of the financial elements and the supply chain of the business model (Aguilar-Fernández \& Otegi-Olaso, 2018). Small businesses face with size 
constraints, which impacts on activities such as investing in accounting information systems, whereas, large businesses possess many resources and infrastructure to invest in innovation (Thong, 1999). Firm size is a contingent factor to explain the degree of formalism in accounting information system design (Ghorbel, 2017). Firm size also has a positive influence on the alignment of accounting information systems (Hajiha \& Azizi, 2011) in which, larger companies adopt information technology usage while smaller businesses have a shortage of formalization of accounting information systems. So, we propose the following null hypotheses:

Null hypothesis $\mathrm{H}_{01}$ : There is no significant difference in system quality of accounting information system based on firm size. Null hypothesis $\mathrm{H}_{02}$ : There is no significant difference in information quality of accounting information system based on firm size.

Business sector describes a group of companies operating in the same segment of the economy or shares a similar business type (Langager, 2019). According to Decree No. 39/2018/NĐ-CP, businesses in Vietnam are classified into three business sectors including the agriculture sector, industry and construction sector, and trade and services sector (Government, 2018). Each business sector suffers from different challenges. For example, the construction sector has to face many constraints such as a high bank rate resulting from a low level of capital, a low technology level, a shortage of maintenance culture, and inadequate training of human resources (Onaolapo \& Odetayo, 2012). And each of these business sectors has a different business process which is a set of tasks and activities coordinating to accomplish a specific goal of the firm (Romney \& Steinbart, 2015). Business processes in business sectors impact on the development of the accounting information system and can trigger the low quality of accounting information systems (Whitten \& Bentley, 2007). The effectiveness of business processes supports the success of accounting information systems implementation (Bagranoff, Simkin, \& Norman, 2010). Ladewi, Susanto, Mulyani, and Suharman (2017) postulated the impact of business processes on the quality of accounting information systems but empirical evidence did not support this relationship. But from actual observation, we agree with suggestions of Whitten and Bentley (2007), Ladewi et al. (2017), and Meiryani and Syaifullah (2015), thus, we propose two hypotheses:

Null hypothesis $\mathrm{H}_{03}$ : There is no significant difference in system quality of accounting information systems based on the business sector.

Null hypothesis $\mathrm{H}_{04}$ : There is no significant difference in information quality of accounting information systems based on the business sector.

\section{Methodology}

The sample framework of this study includes firms operating in Hanoi. This study carried out a survey of stakeholders inside the enterprise, including managers such as board of directors, chief financial officer, head of departments, chief accountant and accounting staff. In this study, the quality of accounting information systems is measured by two dimensions including system quality and information quality. Two constructs are collected from the study of Gorla et al. (2010). The system quality construct comprises 9 items illustrating the characteristics of system processing itself, including "easy to learn, equipped with useful functions and features, flexible to make change easily, applied modern technology, well integrated with other systems, userfriendly, good documentation, quick response to online enquiry, short-time lag in batch processing". The information quality construct is measured by 8 items including "accurate, complete, concise, useful in daily tasks, relevant for decision making, good format and appearance, comparable to other outputs, easy to understand". The study uses a Likert 7-points scale, arranged in ascending order from (1) Strongly disagree to (7) Strongly agree.

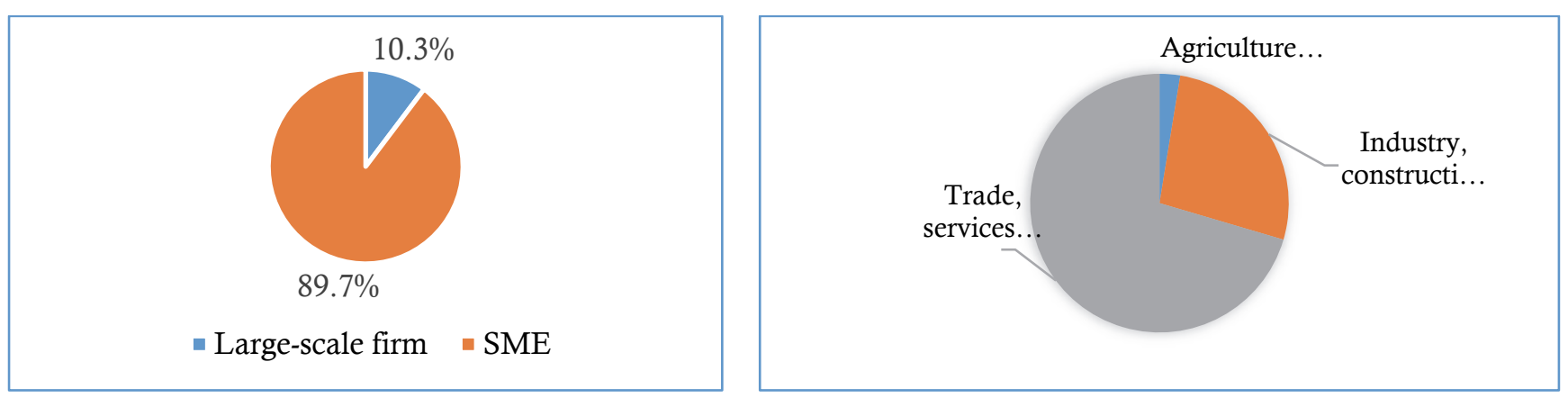

Fig. 1. Demographic of respondents

Data is collected from 504 firms operating in Hanoi that comprise 52 large-scale firms and 452 SMEs. In particular, the size of firms is classified under Decree No. 39/2018/ND-CP (Government, 2018), including small and medium enterprise and largescale enterprise which is based on the criteria of the total asset in the balance sheet. The study used descriptive statistics to show the reality of the quality of accounting information systems and employed one-way ANOVA to test 4 hypotheses. The demographic of data in Fig. 1 shows that SMEs account for a large percentage in the sample. This result heightens previous results that SMEs account for more than $98 \%$ of all business in Vietnam (VCCI, 2017). 


\section{Results and discussions}

\subsection{The descriptive statistic results}

The theoretical model of accounting information system quality in this research includes the two-factor model based on Delone and McLean (1992). Two dimensions comprise system quality and information quality that refer to the quality of information processing system itself and information system output respectively. The descriptive statistical results of accounting information system quality are shown in Table 1.

\section{Table 1}

The descriptive results of accounting information systems quality

\begin{tabular}{|c|c|c|c|c|}
\hline & & $\mathrm{N}$ & Mean & Std. Deviation \\
\hline \multicolumn{5}{|c|}{ System Quality } \\
\hline SQ1 & Easy to learn & 504 & 5.17 & 1.411 \\
\hline SQ2 & Equipped with useful functions and features & 504 & 5.09 & 1.323 \\
\hline SQ3 & Flexible to make change easily & 504 & 5.05 & 1.318 \\
\hline SQ4 & Applied modern technology & 504 & 5.16 & 1.367 \\
\hline SQ5 & Well-integrated & 504 & 5.13 & 1.471 \\
\hline SQ6 & User-friendly & 504 & 5.30 & 1.241 \\
\hline SQ7 & Good documentation & 504 & 5.38 & 1.313 \\
\hline SQ8 & Quick response to an online inquiry & 504 & 5.02 & 1.428 \\
\hline SQ9 & Short-time lag in batch processing & 504 & 5.00 & 1.387 \\
\hline \multicolumn{5}{|c|}{ Information Quality } \\
\hline IQ1 & Accurate & 504 & 5.50 & 1.229 \\
\hline IQ2 & Complete & 504 & 5.50 & 1.208 \\
\hline IQ3 & Concise & 504 & 5.42 & 1.285 \\
\hline IQ4 & Useful in daily tasks & 504 & 5.59 & 1.187 \\
\hline IQ5 & Relevant for decision making & 504 & 5.44 & 1.248 \\
\hline IQ6 & Good format and appearance & 504 & 5.36 & 1.251 \\
\hline IQ7 & Comparable to other outputs & 504 & 5.47 & 1.250 \\
\hline IQ8 & Easy to understand & 504 & 5.48 & 1.250 \\
\hline
\end{tabular}

The study makes a comparison of the quality of accounting information systems among enterprises by the size of firms and the business sector that is classified according to Decree No. 39/2018/NĐ-CP (Government, 2018). By the firm size criteria, there are large-scale enterprise and SME while there are three types of the business sector: agriculture sector, industry - construction sector, and trade and services sector. The results are shown in Fig. 2.
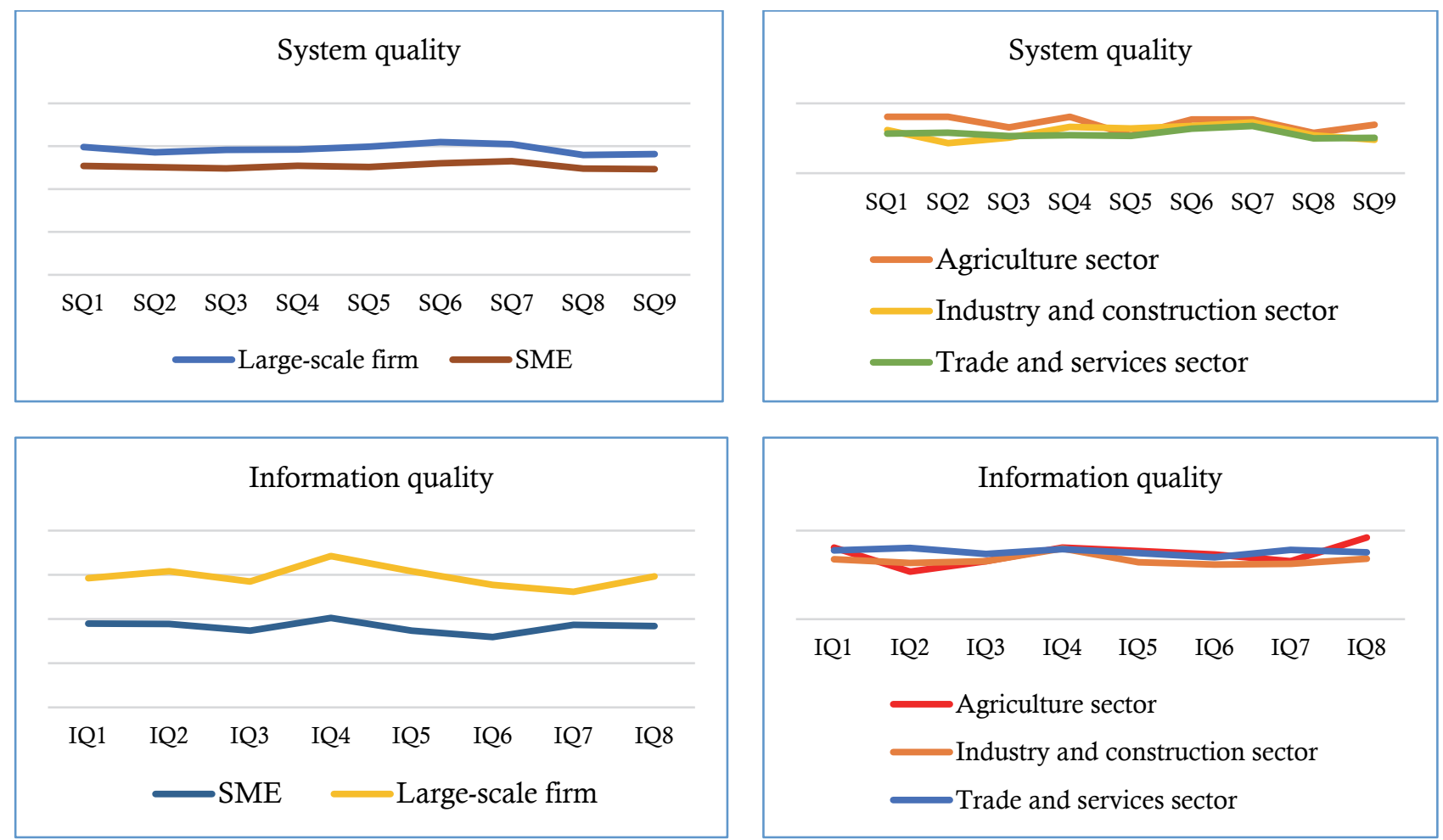

Fig. 2. The comparison of the quality of accounting information system by firm size and business sector 


\subsection{The reliability and validity of the construct}

To examine the consistency of constructs, the paper conducts reliability analysis with SPSS 20. The Cronbach $\alpha$ coefficients should be greater than .60 and the item-total correlation has to be greater than .30 which shows adequate reliability of scale (Nguyen, 2013). According to Field (2009), social science often tries to measure things which cannot directly be measured by latent variable. Quality in this study is subjective measure (ACCA, 2019) and it is difficult to measure directly. So this research employees exploratory factor analysis (EFA) to examine the factorial validity of the measure. The result indicates that the system quality construct and the information quality construct of the accounting information system quality all had high reliabilities, Cronbach's $\alpha=.939$ and .950 respectively (good according to Field (2009)) and all item - total correlations are greater than .30. The high consistency is performed by reliability indices. Principal component analysis is conducted on the 17 items with varimax rotation. The Kaiser-Meyer-Olkin test verifies the sampling adequacy, $\mathrm{KMO}=.94$, which is well above the acceptable limit of .50 (Field, 2009). Bartlett's test of sphericity $\chi^{2}(136)=7886.985$, P-value $<.00$, reveals that correlations between items are sufficiently large for principal component analysis. An initial analysis is implemented to obtain eigenvalues for each component in the data. Two components that have eigenvalues over Kaiser's criterion of 1 explained $70.916 \%$ of the variance. The items that cluster on the same components recommend that component 1 performs system quality, component 2 information quality. The latent variable system quality (SYSQUAL) and information quality (INFQUAL) are computed by mean of component 1 and component 2 respectively. Fig. 3 shows the mean of SYSQUAL and INFQUAL by the size of firms and the business sector.
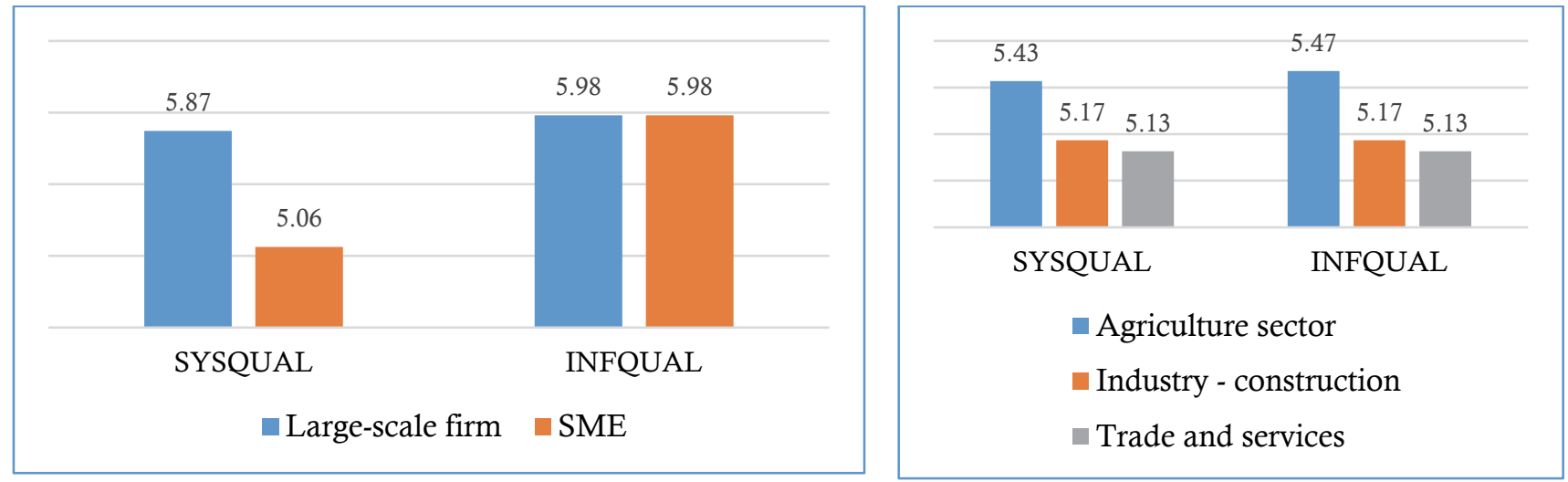

Fig. 3. The quality of accounting information systems by the firm size and business sector

As can be seen in Fig. 3, system quality of the large-scale firms is better than system quality of SMEs (Mean SYSQUAL $=5.87$, Mean $_{\text {IFQUAL }}=5.06$ ). System quality comparing among three sectors of business sectors means of firms in agriculture sector, industry-construction, and trade and services are decreased respectively.

\subsection{The results of test hypotheses}

Test of homogeneity of variances use Leneve statistic, and Leneve's test uses the level significance set a prior for the ANOVA $(\mathrm{P}$-value $=.05)$ to examine the assumption of homogeneity of variance. The research uses One-way ANOVA to test four hypotheses, the null hypotheses are accepted if P-value of ANOVA $>.05$ or alternative hypotheses are accepted if $\mathrm{P}$-value of ANOVA $<.05$ (Field, 2009). The testing results are presented in Table 2. Two aspects of the quality of accounting information systems are shown in the dependent list.

Table 2

The results of One-way ANOVA

\begin{tabular}{|c|c|c|c|c|c|c|}
\hline \multirow[b]{2}{*}{ Dependent list } & \multirow{2}{*}{ Factor } & \multicolumn{2}{|c|}{ Leneve test } & \multicolumn{2}{|c|}{ ANOVA test } & \multirow{2}{*}{ Null hypothesis } \\
\hline & & F-value & P-value & F-value & P-value & \\
\hline SYSQUAL $\left(\mathrm{H}_{01}\right)$ & Firm size & .004 & .951 & 24.693 & .000 & Reject \\
\hline INFQUAL $\quad\left(\mathrm{H}_{02}\right)$ & Firm size & 5.964 & .015 & 13.203 & .000 & - \\
\hline SYSQUAL $\left(\mathrm{H}_{03}\right)$ & Business sector & 2.562 & .078 & .508 & 602 & Accept \\
\hline INFQUAL $\left(\mathrm{H}_{04}\right)$ & Business sector & 248 & .780 & 1.536 & .216 & Accept \\
\hline
\end{tabular}

\section{Discussion}

\subsection{The descriptive results}

The picture of the quality of accounting information systems is revealed in Table 1 and Fig. 2. With the 7-points scale, the descriptive results demonstrate that the user are not completely satisfied with the quality of accounting information systems. The differences in the accounting information system quality are detailed in Fig. 2. Regarding the firm size, the results of comparing accounting information system quality indicate that the perceived quality of the large-scale enterprises is better than 
the perceived quality of SMEs. A detailed analysis of the results is shown in Figure 2 . The overall results show that system quality of the large - scale enterprises is evaluated better than that of SMEs. In the same vein, large enterprises also illustrate an overperformance of information quality, comparing with SMEs. However, while the system quality is stable, the information quality fluctuates. Specifically, system quality illustrates that all criteria of system quality in large-scale enterprises are superior to SMEs, and the gap of system quality between two groups of different sized firms is stable. In both groups, the characteristics of system quality in terms of "user-friendly" (SQ6) and "good documentation" (SQ7) are better evaluated than the rest of system quality indicators. In contrast, the characteristics of "quick response to an online inquiry" (SQ8) and "short-time lag in batch processing" (SQ9) are rated lowest on both two groups. These results reveal that the application of hardware and software is suitable for the competence of employees and the system documentation is set up that facilitating the information processing of the accounting information system. However, the application of information technology in the context of Industry Revolution 4.0 is still limited because the software applied in the accounting information system has low interoperability online. Referring to information quality, the user perception for "useful in daily tasks" (IQ4) is highly appreciated in both large-scale enterprises and SMEs. While in the large-scale enterprises, the criterion of "comparable to other outputs" (IQ7) is perceived at the lowest rated, in small businesses, the criterion of "good format and appearance" (IQ6) is rated at the lowest level. Due to the complexity of business characteristics, large-scale enterprises face the limitations of information connection among subsystems, while because of limited resources, SMEs face the problem of the degree of formalism.

Regarding the business sector, the quality of accounting information systems is compared by three groups including the agriculture sector, industry - construction sector, and trade - service sector. System quality of firms operating in the agriculture sector is perceived better than the other firms operating in the rest sectors, except for the criterion "well integrated with other systems" (SQ5). Besides, the perceived system quality in the industry and construction sector is better than the others operating in the trade and services sector, except for the criterion "equipped with useful functions and features" (SQ2). The accounting information system of firms doing business in the agriculture sector has better quality, but the number of these firms is only 13/504 respondents. Because of the sample framework of this study in Hanoi, the capital of Vietnam, is an economic centerpoint area, thus, there is a low rate of the firm operating in the agriculture sector. So, this study focuses on analyzing the results of two types that account for a large proportion in Hanoi including industry and construction sector (136/504 respondents) and trade and services sector (355/504 respondents). Due to the complicated characteristics of business organizations, the system quality in the industry and construction sector has the most restrictive characteristics of useful functions and features equipped in the system. The fact shows that most businesses apply pre-designed software packages, which are designed to provide common features for all types of businesses, while few businesses design their own packages software depending on their organizational characteristics. Although a software package has many functions, its tools are still not appropriate for all users. So if firms have enough resources, they should design their system. The system quality of the trade and services sector is rated by users as the lowest among the three sectors. The most likely causes of this situation are business characteristics of the trade and services sector which are simpler than the other types. Thus, the firms in this sector invest in the accounting information system at a lower level. The results of information quality in 3 business sectors show that although the system quality of the trade and services sector is lower than the quality of the other two sectors, information quality is evaluated better by users. This can be explained by the organizational characteristics of the trade and services sector which are less complicated than the other two sectors, so the information needs of stakeholders are better met. The results in this research make theoretical contributions. Firstly, the study reinforces the previous research results that the quality of accounting information systems is complex and illusive (Petter et al., 2008). So the use of multi-criteria scales will reflect the aspects of quality. Secondly, the result also agrees with the assertions of previous researchers such as Delone and McLean (2002) that system quality and information quality are the two best measures. The combination of system quality and information quality reflects both the quality of data processing and the quality of output information. Both system quality and information quality in Vietnamese enterprises are not really outstanding. This can lead to unreliable accounting information for decision-making, similar to the result of Nguyen (2018).

\subsection{The results of hypotheses testing}

Regarding the system quality, the hypothesis $\mathrm{H}_{1}$ examines the relationship between the system quality and the firm size while the hypothesis $\mathrm{H}_{3}$ tests the relationship between the system quality and the business sector. Test of homogeneity of variances using Leneve statistics is shown in Table 2, there is no significant difference between the two group's variance of the firm size and among the three group's variance of the business sector. The assumption of homogeneity of variance is met. The firm size has a significant impact on the system quality $\left(\mathrm{F}_{(1,502)}=24.693\right.$, P-value $\left.=.000\right)$ while business sector has no effect on the system quality $\left(\mathrm{F}_{(2,501)}=.508, \mathrm{P}\right.$-value $\left.=.602\right)$. For the information quality, the hypothesis $\mathrm{H}_{2}$ and $\mathrm{H}_{4}$ test the relationship between the information quality and the firm size, and between the information quality and the business sector. The $F$ value of Leneve statistic of the hypothesis $\mathrm{H}_{2}$ is 5.964 , with $\mathrm{P}$-value $=.015(\mathrm{P}$-value $<.05)$ that shows a no homogeneity of variance between the two groups of the firm size. Thus, that is no conclusion on the difference in information quality based on the firm size. Meanwhile, the Leneve test result of hypothesis $\mathrm{H}_{4}$ meets the assumption of homogeneity of variance $(\mathrm{F}=.248, \mathrm{P}-\mathrm{value}=.780)$, but the ANOVA result accepts the null hypothesis that is no significant difference in information quality of accounting information system based on the business sector. With four proposed hypotheses, the results of this study do not conclude about 
the hypothesis $\mathrm{H}_{02}$ due to the heterogeneous variance between two groups. The null hypothesis $\mathrm{H}_{01}$ is rejected exposing a relationship between the size of firm and system quality. The descriptive result in Figure 3 demonstrates that large-companies have a higher system quality than SMEs. SMEs in Vietnam face many resource constraints and suffer from barries to investing in infrastructure of the accounting information system. The large-scale firms have more abundant resources to facilitate their information system. This result reinforces the study of Thong (1999) or Hajiha and Azizi (2011) on advantages of firm size to system quality. The acceptance of null hypotheses $\mathrm{H}_{03}$ and $\mathrm{H}_{04}$ show that there is no relationship between the business sector and the quality of accounting information systems. Each business sector has a different business process that leads to a difference in the accounting information system quality (Ladewi et al., 2017; Meiryani \& Syaifullah, 2015). However, many other determinants affect the quality of accounting information systems such as top management support, manager participation in implementing accounting information systems, information technology, accounting staff, and so on. These determinants help eliminate disparity in the quality of accounting information systems among business sectors.

\section{Conclusion}

This research has explored the quality of accounting information systems. The quality of accounting information systems is measured by a multidimensional scale. Whilst system quality refers to the quality of information processing, information quality performs the characteristics of output quality. System quality and information quality are two good measures to evaluate the quality of accounting information systems. The level of accounting information system quality of firms in Vietnam is not firstrate. This paper has compared system quality and information quality under a diversity of conditions and demonstrates some different characteristics in each group of business sector or firm size. The result has found support for hypothesis $\mathrm{H}_{01}$, which proposes a link between system quality and firm size. The results do not support the association between information quality and firm size. There is no link between system quality and business sector and no association between information quality and business sector as well. The results suggest that the size of firms (which based on the total capital) is a determinant impact on the quality of accounting information systems in the aspect of information processing. Based on the results, the study has implications for managers to improve business performance. Businesses in different size groups or businesses in different business sector groups need to overcome limitations on system quality and information quality. In the context of the IR4.0, many transactions are digitized such as transactions with e-tax system or e-banking system. Thus, firms need to invest to technology, because technologies impact accounting (Kruskopf et al., 2019), to increase the characteristics of information processing systems like "quick response to an inquiry" or "short-time lag in batch processing". The results of this study are crucial because they highlight that state agencies should determine which policies issued for SMEs or which issued for large companies. Making support policies appropriate to each type of business to improve the effectiveness of these policies.

\section{References}

ACCA. (2019). Performance Management - Study text. London: BPP Learning Media Ltd.

Aguilar-Fernández, M. E., \& Otegi-Olaso, J. R. (2018). Firm size and the business model for sustainable innovation. Sustainability, 10(12), 4785. doi: https://doi.org/10.3390/su10124785

AICPA. (1966). Statement of Basic Accounting Theory. New York: AICPA Publication.

Allahverdi, M. (2011, 12-14 Oct. 2011). A general model of accounting information systems. Paper presented at the Application of Information and Communication Technologies (AICT), 2011 5th International Conference on, Baku, Azerbaijan.

Bagranoff, N. A., Simkin, M. G., \& Norman, C. S. (2010). Core concepts of accounting information systems (Eleventh ed.). Hoboken, NJ: Wiley.

Becker, G. S., \& Murphy, K. M. (1992). The division of labor, coordination costs, and knowledge. The Quarterly Journal of Economics, 107(4), 1137-1160.

Binh, V. T. T. (2018). Nghiên cứu các yếu tố ảnh hương đến mức độ trang bị công nghệ thông tin của hệ thống thông tin kế toán doanh nghiẹp [Research on factors affecting IT sophistication of accounting information system]. Paper presented at the Hội thảo khoa học quốc gia Nghiên cứu và đào tạo Kế toán, kiểm toán, Đại học Công nghiệp Hà Nội, Hà Nội.

Chalu, H. (2012). Analysis of Stakeholder Factors Influencing the Effectiveness of Accounting Information Systems in Tanzania's Local Authorities. Business Management Review, 16(1), 1-32.

Chúc, A. T. (2015). Thông tin kế toán hữu ích trong điều kiện ứng dụng CNTT [Useful accounting information in terms of IT application]. Tạp chí Tài Chính, Tháng 2.

Delone, W. H., \& McLean, E. R. (1992). Information Systems Success: The Quest for the Dependent Variable. Information Systems Research, 3(1), 60-95. doi: https://doi.org/10.1287/isre.3.1.60

Delone, W. H., \& McLean, E. R. (2002). Information systems success revisited. Paper presented at the System Sciences, 2002. HICSS. Proceedings of the 35th Annual Hawaii International Conference on.

Delone, W. H., \& McLean, E. R. (2003). The DeLone and McLean Model of Information Systems Success: A Ten-Year Update. Journal of Management Information Systems, 19(4), 9-30. doi: 10.1080/07421222.2003.11045748

Field, A. (2009). Discovering statistics using SPSS (Sage ed.). Dubai: Oriental Press.

Ghorbel, J. (2017). A Study of Contingency Factors of Accounting Information System Design in Tunisian SMIs. Journal of the Knowledge Economy, 1-30. doi: https://doi.org/10.1007/s13132-016-0439-8 
Gorla, N., Somers, T. M., \& Wong, B. (2010). Organizational impact of system quality, information quality, and service quality. Journal of Strategic Information Systems, 19, 207-228. doi: https://doi.org/10.1016/j.jsis.2010.05.001

Government. (2018). Nghi định 39/2018/ND-CP: Quy định chi tiết một số điều của Luật hỗ trợ doanh nghiệp nhỏ và vìa [Decree no. 39/2018/ND-CP: Detailed regulations on some articles of the Law to support small and medium enterprises].

Hajiha, Z., \& Azizi, Z. A. P. (2011). Effective factors on Alignment of Accounting Information Systems in Manufacturing Companies: Evidence from Iran. Information Management and Business Review, 3(3), 158-170.

Hartmann, M., Oriani, R., \& Bateman, H. (2013). The performance effect of business model innovation: An empirical analysis of pension funds The 35th DRUID Celebration Conference

Kieso, D. E., Weygandt, J. J., \& Warfield, T. D. (2010). Intermediate accounting: IFRS edition (Vol. 2): John Wiley \& Sons.

Kruskopf, S., Lobbas, C., Meinander, H., Söderling, K., Martikainen, M., \& Lehner, O. M. (2019). Digital accounting: opportunities, threats and the human factor. ACRN Oxford Journal of Finance and Risk Perspectives, 8(2019)(Special Issue Digital Accounting), 1-15.

Ladewi, Y., Susanto, A., Mulyani, S., \& Suharman, H. (2017). Critical Factors Accounting Information System Success Survey of State-Owned Enterprises (SOE) in Indonesia. International Journal, 10(1).

Langager, C. (2019, Apr 12, 2019). Industry vs. sector: What's the difference? Retrieved Nov 11, 2019, from https://www.investopedia.com/ask/answers/05/industrysector.asp

Meiryani. (2015). Influence Business Strategy on the Quality of Accounting Information System. International Journal of Scientific \& technology research, 4(2), 80-86.

Meiryani, \& Syaifullah, M. (2015). Influence Business Process On The Quality Of Accounting Information System. International Journal of Scientific \& technology research, 4(1), 323-328.

Nguyen, B. N. (2018). Báo cáo tài chính của doanh nghiệp nhỏ và vừa - đối tượng sử dụng và chất lượng thông tin trên báo cáo tài chính [Finacial reporting of small and medium enterprises: users and information quality]. Tạp chí Khoa hoc \& Đào tạo Ngân hàng, 192(tháng 5), 28-34.

Nguyen, D. T. (2013). Giáo trình phuoong pháp nghiên cứu khoa học trong kinh doanh [Research method in business]. Trường Đại học Kinh tế TP. Hồ Chí Minh: Nhà xuất bản Tài chính.

Nguyen, T. B. L. (2012). Xác định và kiểm soát các nhân tố ảnh hưởng chất luợng thông tin kế toán trong môi truờng ứng dụng hệ thống hoạch định nguồn lực doanh nghiệp (ERP) tại các doanh nghiệp Việt Nam [Determine and control factors affecting information quality in ERP environment in Vietnamese enterprises]. (Thesis), Trường Đại học kinh tế thành phố Hồ Chí Minh.

Onaolapo, A. A., \& Odetayo, T. A. (2012). Effect of Accounting Information System on Organizational Effectiveness: A case study of Selected Contruction Companies in Ibadan, Nigeria. American Journal of Business and Management, 1(4), 183189.

Petter, S., Delone, W. H., \& McLean, E. R. (2008). Measuring information systems success: models, dimensions, measures, and interrelationships. European journal of information systems, 17, 236-263. doi: https://doi.org/10.1057/ejis.2008.15

Romney, M. B., \& Steinbart, P. J. (2015). Accounting information systems: Pearson Boston, MA.

Sačer, I. M., \& Oluić, A. (2013). Information Technology and Accouting Information Systems' Quality in Croatian Middle and Large Companies. Journal of Informatiion and Organizational Sciences, 37(2), 117-126.

Sajady, H., Dastgir, M., \& Nejad, H. H. (2008). Evaluation of the effectiveness of accounting information systems. International journal of information science and technology, 6(2), 49-59.

Seddon, P. B. (1997). A respecification and extension of the DeLone and McLean model of IS success. Information Systems Research, 8(3), 240-253. doi: https://doi.org/10.1287/isre.8.3.240

Seddon, P. B., \& Kiew, M. Y. (1996). A Partial Test and Development of Delone and McLean's Model of IS Success. Australian Journal of Information Systems, 4(1), 90-109. doi: http://dx.doi.org/10.3127/ajis.v4i1.379

Smith, A. (1776). An inquiry into the nature and causes ofthe wealth ofnations. London: George Routledge and Sons.

Thong, J. Y. L. (1999). An integrated model of information systems adoption in small businesses. Journal of Management Information Systems, 15(4), 187-214. doi: https://doi.org/10.1080/07421222.1999.11518227

VCCI. (2017). Báo cáo thường niên doanh nghiệp Việt Nam 2016 [Annual reporting: Vietnameses Enterprises in 2016].

Weill, P., \& Olson, M. H. (1989). An Assessment of the Contingency Theory of Management Information Systems. Journal of Management Information Systems, 6(1), 59-86. doi: DOI: 10.1080/07421222.1989.11517849

Whitten, J. L., \& Bentley, L. D. (2007). Systems analysis and design. London: McGraw-Hill.

Yap, C. S., Soh, C. P., \& Raman, K. S. (1992). Information Systems Success Factors in Small Business. OMEGA International Journal of Management Science, 20(5/6), 597-609.

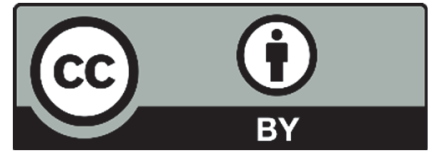

(C) 2020 by the authors; licensee Growing Science, Canada. This is an open access article distributed under the terms and conditions of the Creative Commons Attribution (CC-BY) license (http://creativecommons.org/licenses/by/4.0/). 